\title{
Advances in Neurotrophic Factor and Cell-Based Therapies for Parkinson's Disease: A Mini-Review
}

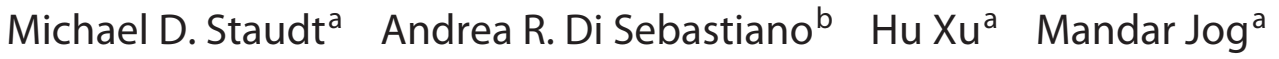 \\ Susanne Schmid ${ }^{c}$ Paula Foster ${ }^{d, e}$ Matthew O. Hebb ${ }^{a, c}$ \\ Departments of a Clinical Neurological Sciences, ${ }^{b}$ Physiology and Pharmacology, ${ }^{c}$ Anatomy and Cell Biology, and \\ ${ }^{\mathrm{d}}$ Medical Biophysics, Schulich School of Medicine and Dentistry, Western University, and ${ }^{\mathrm{e}}$ Imaging Research \\ Laboratories, Robarts Research Institute, London, Ont., Canada
}

\section{Key Words}

Stem cells · Progenitors · Induced pluripotent stem cells .

Transplantation $\cdot$ Neurodegeneration

\begin{abstract}
Parkinson's disease (PD) affects an estimated 7-10 million people worldwide and remains without definitive or disease-modifying treatment. There have been many recent developments in cell-based therapy (CBT) to replace lost circuitry and provide chronic biological sources of therapeutic agents to the PD-affected brain. Early neural transplantation studies underscored the challenges of immune compatibility, graft integration and the need for renewable, autologous graft sources. Neurotrophic factors (NTFs) offer a potential class of cytoprotective pharmacotherapeutics that may complement dopamine (DA) replacement and CBT strategies in PD. Chronic NTF delivery may be an integral goal of CBT, with grafts consisting of autologous drug-producing (e.g., DA, NTF) cells that are capable of integration and function in the host brain. In this mini-review, we outline the past experience and recent advances in NTF technology and CBT as promising and integrated approaches for the treatment of PD.

(c) 2015 S. Karger AG, Basel
\end{abstract}

\section{Introduction}

Parkinson's disease (PD) is the second most common neurodegenerative disorder, with a prevalence of $1-2 \%$ in people older than 60 years, and $0.3 \%$ in the general population [1]. There is currently no cure or diseasemodifying treatment available; however, recent medical advances offer promise of tangible and effective strategies to preserve and restore neurological function in PD patients. The efficacy of neurotrophic factor (NTF) administration and cell-based therapy (CBT) achieved in preclinical models has propelled therapeutic initiatives in PD and other neurological disorders. The challenge remains, however, to effectively translate these developments into clinical practice. The goal of this mini-review is to synthesize the current state of knowledge and discuss the future prospects for NTF-based approaches and CBT in PD.

M.D. Staudt and A.R. Di Sebastiano contributed equally to this paper.

\section{KARGER}

E-Mail karger@karger.com

www.karger.com/ger
(C) 2015 S. Karger AG, Basel

0304-324X/15/0623-0371\$39.50/0
Matthew O. Hebb, MD, PhD, FAANS, FRCSC

Department of Clinical Neurological Sciences

Schulich School of Medicine and Dentistry, Western University

339 Windermere Road, London, ON N6A 5A5 (Canada)

E-Mail mhebb@uwo.ca 


\section{Clinical Aspects of PD}

The pathological hallmark of $\mathrm{PD}$ is a progressive loss of mesencephalic dopamine (DA) neurons; however, the disease widely affects both neurons and nonneuronal cells in the central, peripheral and autonomic nervous systems. Bradykinesia (i.e., slowness of movement), rigidity and rest tremor are common motor symptoms that may be accompanied by gait and postural imbalance, neuropsychiatric and sleep disorders, sensory dysfunction and dysautonomia. Late-stage patients often succumb to respiratory infection, and the mean duration from diagnosis to death is 15 years. Clinical diagnosis of PD is based on validated and standardized criteria, with a genetic etiology identified in only $10-15 \%$ of patients [2, $3]$. There are no widely accepted biomarkers for disease confirmation or prognosis, and a pathological diagnosis may ultimately be obtained at autopsy. Nonmotor PD features, such as dementia, depression, gastrointestinal or sexual dysfunction, are managed symptomatically. The combination of levodopa and the peripheral dopa decarboxylase inhibitor, carbidopa, is the most effective medical therapy for PD motor symptoms. Carbidopa prevents the peripheral conversion of levodopa to DA, allowing for a greater effect in the central nervous system (CNS). DA agonists, inhibitors of DA metabolism (e.g., catechol-Omethyl transferase and monoamine oxidase B inhibitors), anticholingeric agents and amantadine may offer additional or alternative medication options. Unfortunately, these agents often provide only partial symptom control and require dose titration and polypharmacy, with frequent development of medication-related symptoms, such as neuropsychiatric, gastrointestinal and motor dysfunction. Wearing-off (i.e., loss of therapeutic effect before the subsequent medication dose) and dyskinesia (i.e., involuntary movements) are disabling and common motor manifestations in patients on long-term levodopa therapy $[4,5]$. Complementing medical therapy is deep brain stimulation (DBS), which is now the standard of surgical care for PD [6]. The mechanisms by which DBS exerts therapeutic effects are not entirely clear; however, those who respond to treatment may exhibit improvement in certain motor symptoms (i.e., tremor, bradykinesia, rigidity) and tolerate reductions in medication doses that lessen associated side effects. Surgical candidacy is based upon an accurate diagnosis, response to pharmacotherapy, medical comorbidities, performance status and cognitive function. Despite diligent preoperative screening, some patients will fail to benefit or exhibit intolerable side-effects or surgical complications from DBS.

\section{NTF Therapy for PD}

The rationale for pursuing NTFs as therapeutic agents for PD stems from their known roles in neuronal survival, differentiation and plasticity. Additionally, NTF deficiency has been associated with $\mathrm{PD}$, and replacement or enhancement of NTF signaling confers neuronal protection in both in vitro and in vivo preclinical PD models [7]. These proteins regulate vital biological programs in the developing and adult nervous systems and are currently the most potent cytoprotective agents known against PD-related degeneration in the brain [8]. The four main NTF families are: (1) glial-derived neurotrophic factor (GDNF) family of ligands: GDNF, neurturin (NTRN), persephin and artemin; (2) neurotrophins: nerve growth factor, brainderived neurotrophic factor (BDNF), neurotrophin-3, neurotrophin-4; (3) neuropoietic cytokines (neurokines): ciliary NTF, leukemia inhibitory factor, interleukin-6, cardiotrophin-1, oncostatin $\mathrm{M}$, and (4) cerebral DA neurotrophic factor $(\mathrm{CDNF}) /$ mesencephalic astrocyte-derived NTF family. Several excellent reviews are available that outline the data and rationale behind the development of NTF-based therapeutics for PD [7-9]. Of the various NTF members, GDNF has received the most clinical attention and continues to be evaluated in patient trials (table 1).

\section{Glial-Derived Neurotrophic Factor}

GDNF is one of the most widely investigated cytoprotective agents considered for PD therapeutics, supported by robust preclinical evidence of beneficial effects on dopaminergic neuron survival, regeneration, phenotype and function in cellular and animal PD models $[10,11]$. Numerous reports have also described the physiological and behavioral benefits of GDNF-producing cells when transplanted into the brains of parkinsonian animals. The experimental models varied widely and included polymer encapsulation to protect the cells from immune destruction, genetically engineered and native GDNF production, a host of cell types and sources, and various nonhuman species and PD models [9]. GDNF has been studied in four clinical trials using direct microinfusion into the ventricular system or putamen [8]. The first clinical study was a multicenter, randomized, double-blind, placebo-controlled trial (RDBCT) that compared the effects of monthly intracerebroventricular administration of placebo and escalating doses of recombinant methionyl human GDNF (r-metHuGDNF; Liatermin ${ }^{\circledR}$; Amgen) in 50 subjects with PD for 8 months. Unfortunately, 'on' and 'off total and motor Unified Parkinson's Disease Rating Scale (UPDRS) scores were not improved by 
Table 1. Prevailing NTF and CBT clinical trials for PD

\begin{tabular}{|c|c|c|c|c|c|}
\hline $\begin{array}{l}\text { Study } \\
\text { design }\end{array}$ & Study protocol & $\begin{array}{l}\text { Size/ } \\
\text { duration }\end{array}$ & Outcome & Adverse events & $\begin{array}{l}\text { Authors } \\
\text { [Ref.], year }\end{array}$ \\
\hline \multicolumn{6}{|c|}{ GDNF(r-metHuGDNF) intervention } \\
\hline $\begin{array}{l}\text { RDBCT, } \\
\text { phase } 1 / 2\end{array}$ & $\begin{array}{l}\text { Intracerebroventricular infusion; } \\
\text { monthly administration }\end{array}$ & $\begin{array}{l}50 \text { patients/ } \\
8 \text { months }\end{array}$ & $\begin{array}{l}\text { No significant change in total or motor } \\
\text { UPDRS scores }\end{array}$ & $\begin{array}{l}\text { Nausea, anorexia, } \\
\text { paresthesia, } \\
\text { hyponatremia, weight } \\
\text { loss }\end{array}$ & $\begin{array}{l}\text { Nutt et al. } \\
{[12], 2003}\end{array}$ \\
\hline $\begin{array}{l}\text { Open label, } \\
\text { phase } 1\end{array}$ & $\begin{array}{l}\text { Intraparenchymal continuous } \\
\text { infusion into the posterior dorsal } \\
\text { putamen; unilateral in } 1 \text { patient, } \\
\text { bilateral in } 4 \text { patients }\end{array}$ & $\begin{array}{l}5 \text { patients/ } \\
1 \text { year }\end{array}$ & $\begin{array}{l}39 \% \text { improvement in the off-medication } \\
\text { UPDRS motor score, } 61 \% \text { improvement } \\
\text { in the ADL score; } 64 \% \text { reduction in } \\
\text { medication-induced dyskinesias; } \\
{\left[{ }^{18} \mathrm{~F}\right] \text { dopa uptake showed a significant }} \\
28 \% \text { increase in putamen dopamine } \\
\text { storage after } 18 \text { months }\end{array}$ & Paresthesia & $\begin{array}{l}\text { Gill et al. } \\
{[13], 2003}\end{array}$ \\
\hline $\begin{array}{l}\text { Open label, } \\
\text { phase } 1\end{array}$ & $\begin{array}{l}\text { Intraparenchymal continuous } \\
\text { infusion into the posterior dorsal } \\
\text { putamen; unilateral }\end{array}$ & $\begin{array}{l}10 \text { patients/ } \\
24 \text { weeks }\end{array}$ & $\begin{array}{l}\text { UPDRS total scores in the 'on' and 'off } \\
\text { states significantly improved } 34 \text { and } \\
33 \% \text {, respectively; UPDRS motor scores } \\
\text { in both the 'on' and 'off states } \\
\text { significantly improved by } 30 \%\end{array}$ & Paresthesia & $\begin{array}{l}\text { Slevin et al. } \\
{[16], 2005}\end{array}$ \\
\hline $\begin{array}{l}\text { RDBCT, } \\
\text { phase } 1 / 2\end{array}$ & $\begin{array}{l}\text { Intraparenchymal continuous } \\
\text { infusion into the posterior dorsal } \\
\text { putamen; bilateral }\end{array}$ & $\begin{array}{l}34 \text { patients/ } \\
6 \text { months }\end{array}$ & $\begin{array}{l}\text { No significant change in UPDRS scores; } \\
32.5 \% \text { increase in mean }\left[{ }^{18} \mathrm{~F}\right] \text { dopa } \\
\text { uptake }\end{array}$ & $\begin{array}{l}\text { Paresthesia, headaches, } \\
\text { respiratory infections, } \\
\text { GDNF antibodies }\end{array}$ & $\begin{array}{l}\text { Lang et al. } \\
{[17], 2006}\end{array}$ \\
\hline
\end{tabular}

\section{AAV2-GDNF intervention}

Open label, Convection-enhanced delivery of 24 patients/ Study in progress ${ }^{\mathrm{b}}$

phase 1 AAV2-containing human GDNF in 5 years the putamen; bilateral

\begin{tabular}{|c|c|c|c|c|c|}
\hline \multicolumn{6}{|c|}{ Human embryonic mesencephalic transplants ${ }^{\mathrm{a}}$} \\
\hline $\begin{array}{l}\text { RDBCT, } \\
\text { phase } 1 / 2\end{array}$ & $\begin{array}{l}\text { Mesencephalic tissue from } 4 \text { embryos } \\
\text { aborted } 7-8 \text { weeks after conception } \\
\text { implanted into the putamen } \\
\text { bilaterally }\end{array}$ & $\begin{array}{l}40 \text { patients/ } \\
1 \text { year }\end{array}$ & $\begin{array}{l}\text { Clinical improvement in younger }(<60 \\
\text { years old), but not in older patients as } \\
\text { measured by UPDRS and Schwab and } \\
\text { England ADL scores; significant } \\
\text { increase in putamen }\left[{ }^{18} \mathrm{~F}\right] \text { dopa uptake }\end{array}$ & $\begin{array}{l}\text { Subdural hematoma in } \\
1 \text { patient; graft-induced } \\
\text { dyskinesias observed in } \\
15 \% \text { of transplant } \\
\text { patients }\end{array}$ & $\begin{array}{l}\text { Freed et al. } \\
{[30], 2001}\end{array}$ \\
\hline $\begin{array}{l}\text { RDBCT, } \\
\text { phase } 1 / 2\end{array}$ & $\begin{array}{l}\text { Mesencephalic grafts derived from } \\
\text { donor embryos aged } 6-9 \text { weeks; } \\
\text { patients were randomized to bilateral } \\
\text { putamen transplant with } 1 \text { or } 4 \\
\text { donors per side, or placebo }\end{array}$ & $\begin{array}{l}34 \text { patients/ } \\
2 \text { years }\end{array}$ & $\begin{array}{l}\text { Nonsignificant trend towards } \\
\text { improvement in UPDRS motor score in } \\
\text { whole group, but significant } \\
\text { improvement in subgroup with less } \\
\text { severe disease; transplants with either } \\
1 \text { or } 4 \text { donors produced a significant } \\
\text { increase in putamen }\left[{ }^{18} \mathrm{~F}\right] \text { dopa uptake }\end{array}$ & $\begin{array}{l}\text { Graft-induced } \\
\text { dyskinesias observed in } \\
56 \% \text { of transplant } \\
\text { patients }\end{array}$ & $\begin{array}{l}\text { Olanow et } \\
\text { al. [31], } \\
2003\end{array}$ \\
\hline
\end{tabular}

\section{TRANSEURO trial}

Open label, Bilateral fetal mesencephalic $\quad 40$ patients/ Study in progress ${ }^{c}$

phase 1 grafts in patients with early PD 3 years

${ }^{a}$ Numerous small, unblinded studies have been reported to produce significant clinical benefit for PD patients; only the RDBCTs are listed here.

${ }^{\mathrm{b}}$ https://www.clinicaltrials.gov/ct2/show/NCT01621581.

${ }^{c} \mathrm{https} / / /$ clinicaltrials.gov/ct2/show/NCT01898390.

GDNF; however, treated patients had common adverse effects, including nausea, vomiting and paresthesias. Sixteen of these patients were then followed in an open-label study for up to an additional 20 months, with no further improvement in PD symptoms. It was felt that the adverse effects resulted from off-target GDNF influence and the lack of therapeutic benefit from an inability of
GDNF to diffuse into the parenchyma from the ventricular source [12]. A subsequent open-label study that enrolled $5 \mathrm{PD}$ patients investigated the effects of intraparenchymal delivery of GDNF via implanted catheters in the dorsal putamen (unilateral in 1 patient; bilateral in 4 patients) and connected to an extracranial pump system [13]. After 1 year, there were no serious clinical side ef- 
fects, a $39 \%$ improvement in the off-medication UPDRS motor scores and a $61 \%$ improvement in the activities of daily living subscore. Medication-induced dyskinesias were considerably reduced, and positron emission tomography (PET) scans of $\left[{ }^{18} \mathrm{~F}\right]$ dopa uptake showed a significant $28 \%$ increase in putamen DA storage after 18 months [14]. In a follow-up report, the group described one of the patients with bilateral GDNF infusions who had received treatment for 39 months, then was followed clinically and with PET for another 36 months. The UPDRS motor and activities of daily living scores 'off medication remained improved by 74 and $76 \%$, respectively, levodopa usage ceased after 1 year, and, at 36 months after GDNF cessation, the $\left[{ }^{18} \mathrm{~F}\right]$ dopa uptake remained 29\% higher in the posterior putamen [15]. Another group led a second open-label study that enrolled 10 patients treated unilaterally with intraputamenal GDNF [16]. A significant increase in total and motor UPDRS scores was observed after 24 weeks, but the benefit was lost with cessation of treatment. These positive outcomes spurred a second multicenter, placebo-controlled trial in which $34 \mathrm{PD}$ patients were randomized to receive bilateral intraputamenal GDNF ( $15 \mu \mathrm{g} /$ putamen/ day; a dose lower than that of the previous studies) or placebo via continuous infusion. At 6 months, there was no significant treatment benefit reflected in the 'off UPDRS motor scores; however, a 32.5\% increase in putamenal $\left[{ }^{18} \mathrm{~F}\right]$ dopa uptake was observed in the GDNF-treated cohort [17]. The disparate outcomes of these studies may reflect differences in study design, cohort size, drug dosage and/or delivery systems. The r-metHuGDNF manufacturing company subsequently withdrew the agent on the grounds of safety concerns regarding production of neutralizing antibodies in several patients and related cerebellar injuries in animal studies, although no such injuries were reported in human trials. Efforts are now underway to evaluate adenoassociated virus (AAV)-mediated GDNF in an open-label phase I study on patients with advanced PD (https:// www.clinicaltrials.gov/ct2/show/NCT01621581).

\section{Neurturin}

The amino acid sequence of human NTN shares over $40 \%$ homology with GDNF and, accordingly, NTRN confers potent neuroprotection to the nigrostriatal DA system $[18,19]$. In nonhuman primates treated with the dopaminergic neurotoxin 1-methyl-4-phenyl-1,2,3,6-tetrahydropyridine (MPTP), putamenal infusion of NTRN improves parkinsonian behaviors and increases DA metabolite levels in the brain [20]. CERE-120 is an AAV vector expressing
NTRN that has also shown therapeutic potential in preclinical PD studies. Intrastriatal CERE-120 delivery in MPTP-lesioned primates significantly improved motor symptoms and reduced the loss of DA neurons [21]. In a 1-year follow-up study, rhesus monkeys treated with CERE120 showed no evidence of clinical, neurological or systemic toxicity [22]. A phase 1, open-label clinical trial demonstrated safety, tolerability and potential therapeutic benefit in $\mathrm{PD}$ patients after 1 year [23]. A subsequent RDBCT enrolled 58 patients to receive AAV2-NTRN bilaterally into the putamen or sham surgery. The primary endpoint was change from baseline to 12 months in the UPDRS motor score in the off state, and no significant difference was found between patients treated with AAV2-NTRN compared with control individuals. Three of 38 patients in the AAV2-NTRN group and 2 of 20 in the sham surgery group developed tumors, with uncertain relations to the actual treatment [24]. Postmortem analysis of 2 patients revealed that, unlike the animal studies, putamenal AAV-NTRN injections did not confer adequate retrograde labeling of neurons in the substantia nigra (SN) [25]. This deficiency in axonal transport of AAV-NTRN to the SN was addressed in a phase 1 safety study that enrolled 6 patients who received bilateral dual injections into the putamen and SN [26]. Two-year follow-up suggested that the procedures were well-tolerated, and no serious adverse effects were reported. A second phase 2 RDBCT was then conducted, enrolling 51 patients to receive bilateral putamen and SN AAV-NTRN (https://clinicaltrials.gov/ct2/show/ NCT00985517). In 2013, it was announced that the trial did not demonstrate statistically significant improvement in patient UPDRS scores after 15-24 months of follow-up. However, a more robust response to CERE-120 was observed in PD patients treated within 5 years of diagnosis, and no safety concerns were raised. There was a marked placebo effect, and the control and CERE-120-treated patients both improved significantly following surgery. Longterm observational studies of the participants are planned to assess delayed clinical effect (http://www.prnewswire. com/news-releases/ceregene-reports-data-from-parkinsons-disease-phase-2b-study-203803541.html).

\section{CBT for PD}

A primary objective of CBT over the last several decades has been the replacement of neurons to bolster the nigrostriatal dopaminergic system, as measured by improved DA activity on PET studies and PD-related motor symptomatology. However, PD is not a pure motor disor- 
der produced by isolated loss of nigrostriatal DA neurons, but encompasses other neural cell types and brain regions leading to an associated spectrum of cognitive and neuropsychiatric dysfunction $[1,2]$. Thus, it is also appealing to use transplanted cells as pervasive, intracerebral delivery vehicles of naturally produced or genetically engineered therapeutic molecules, such as NTFs. These two approaches are likely to have distinct physiological consequences, with the former providing poorly or nonregulated enhancement of the DA system and the latter supplying trophic molecules that, in theory, should support numerous if not all exposed neural circuitry. The principal tissue sources and cell types being investigated for CBT in PD are embryonic/fetal ventral mesencephalic tissue, native human stem cells [e.g., human embryonic stem cells (hESCs), mesenchymal stem cells (MSCs)], induced pluripotent stem cells (iPSCs), and induced (dopaminergic) neuronal cells (iN and iDA cells). In addition, autologous brain-derived progenitor cells (BDPCs) have been recently described in living PD patients [27]. Each graft option presents advantages and disadvantages, with primary considerations being cell availability, handling properties, phenotype, tumorigenic potential, immunogenicity and ethical acceptability. In addition, transplanted allografts may, theoretically, be affected by the PD phenotype, and autologous cells may carry a genetic predisposition for degeneration. While most of these issues remain to be addressed, it is generally evident that renewable sources of graft substrate are needed and that autologous tissues offer significant advantage over allografts. An ideal graft would presumably consist of autologous drug-producing (e.g., DA, NTF) cells with limited proliferative capacity (i.e., low tumorigenic potential) and a phenotype well-suited to integrate into the host brain following transplantation.

\section{Fetal Ventral Mesencephalic Tissue}

Early preclinical studies using animal PD models that deplete nigrostriatal DA neurons with 6-hydroxydopamine (6-OHDA) or MPTP demonstrated the feasibility and therapeutic benefit of transplanting fetal dopaminergic mesencephalic grafts into the CNS [28]. In the 1980s and 1990s, several open-label studies were reported using transplantation of human fetal DA neurons in PD patients. The clinical outcomes were generally positive and paralleled an increase in $\left[{ }^{18} \mathrm{~F}\right]$ dopa uptake in the grafted striatum that lasted years following transplantation surgery [29]. These findings prompted the National Institutes of Health to sponsor two major RDBCTs, the first of which randomized 40 patients with advanced PD to undergo sham surgery or transplantation of human mesen-

Neurotrophic Factor and Cell Therapies for Parkinson's Disease cephalic tissue grafts bilaterally into the putamen, an area which normally receives robust input from the nigrostriatal DA system. Transplanted patients who were 60 years old or younger exhibited a significant clinical improvement, using standardized clinical PD measures, as compared with those in the sham group 1 year following surgery. No significant improvement was observed with transplantation in patients older than 60 years. Graft survival was confirmed in $85 \%$ of patients in the transplantation group, either by $\left[{ }^{18} \mathrm{~F}\right]$ dopa uptake on PET or postmortem examination. Graft-induced dyskinesias or dystonia was observed in $15 \%$ of transplantation patients [30]. A second study enrolled 34 patients with advanced $\mathrm{PD}$ in a prospective RDBCT of fetal nigral transplantation. Despite evidence of graft survival with PET and at autopsy, the transplanted patients showed no significant improvement in motor function after 24 months. However, a significant benefit was observed in a subset of patients with milder motor dysfunction, suggestive of a neuroprotective, rather than restorative, effect. Over half of the transplanted patients in this study exhibited graft-induced dyskinesias [31]. The results of these two trials were disappointing, and the discrepancy with open-label studies prompted criticism of trial techniques and design. Concerns were raised about potentially confounding issues that prevent the accurate comparison of study outcomes, including a lack of placebo controls in the open trials as well as inter-trial variability in tissue preparation and storage, use of immunosuppression, length of followup and choice of primary outcome measures. Interestingly, a 2- and 4-year follow-up of patients enrolled in the 2001 RDBCT demonstrated progressive clinical improvement that was not restricted by age. There were significant increases in putamenal $\left[{ }^{18} \mathrm{~F}\right]$ dopa uptake over the 4 -year post-transplantation period, and improved clinical measures correlated with retention of the PET signal in this region. Nongrafted patients demonstrated progressive reduction of putamenal $\left[{ }^{18} \mathrm{~F}\right]$ dopa uptake, as is expected with disease progression [32]. To more accurately assess the potential of fetal grafts, a new European study has been designed to optimize and control for patient selection, tissue composition, tissue placement and trial design. TRANSEURO is an open-label, multi-center trial to define the feasibility and efficacy of human fetal ventral mesencephalic grafts in patients with PD (https://clinicaltrials.gov/ct2/show/NCT01898390). The primary outcome of this study is the change in motor UPDRS scores in the absence of PD medications 3 years after transplantation. This new trial will hopefully shed light on the true potential of dopaminergic allografts for PD treatment. 


\section{Native Human Stem Cells}

The past decade has recognized the development of hESC technology for therapeutic purposes in a wide variety of clinical conditions. Due to an innate capacity for selfrenewal and differentiation, hESCs may circumvent some of the technical challenges associated with fetal tissue transplantation. First isolated in 1998 from the inner cell mass of blastocysts, hESCs are pluripotent, with the capacity to differentiate into neurons, astrocytes and oligodendrocytes [33]. An in vitro differentiation assay was developed that directed hESCs into a midbrain DA neuron lineage, which had great implications for future PD research [34]. Initial preclinical transplantations in rat [35] and monkey [36] PD models demonstrated promising functional recovery; however, complications arose regarding cell survival, host immune response and tumorigenicity. Further refinement of hESC derivation processes has been limited due to ethi$\mathrm{cal}$ and political reasons and, as such, the clinical potential of these cells remains largely undefined. Alternative stem cell sources have been investigated for differentiation into a neural lineage, in particular MSCs from bone marrow, umbilical cord blood, dental pulp and adipose tissue sources [37]. Autologous MSCs are favorable due to their availability, potential for differentiation and the absence of ethical issues associated with hESCs. In addition, MSCs have been demonstrated to exert regenerative and neuroprotective effects in a number of animal PD models presumed, in part, due to endogenous NTF expression. A pilot study in 7 PD patients has since demonstrated the feasibility and safety of autologous MSCs in human transplantation, but did not establish clinical efficacy [38].

\section{iPSCs, iN Cells and iDA Cells}

In 2006, Takahashi and Yamanaka [39] reported that mouse fibroblasts can be reprogrammed to a pluripotent state by viral delivery of four transcription factors, Oct4, Sox2, Klf4 and cMyc. The cells were called iPSCs and had a similar morphology and differentiation capacity as hESCs. iPSCs can be driven along various lineage pathways to produce glial and neuronal phenotypes. These cells meet criteria for pluripotency and offer immunological, accessibility and ethical advantages compared to fetal graft and hESC methodologies [40]. Of particular relevance to the treatment of PD is the ability of iPSCs to be reprogrammed into dopaminergic neurons, and their potential as an autologous source for cell replacement in PD patients. Wernig et al. [41] successfully differentiated murine-derived iPSCs into dopaminergic neurons. These cells showed specific markers of DA expression, including the transcription factors Nurr1 and Pitx3, tyrosine hydroxylase and electrophysiological properties of DA neurons. Later studies differentiated dopaminergic neurons from both established human iPSC lines and patient-derived somatic cells. These DA cells were effectively transplanted into a 6-OHDA rat model of PD, leading to significant behavioral improvements [42]. Despite these successes, a number of factors have previously stood in the way of using these cells for human therapy, including the risk of tumorigenicity and the use of virus-modified cell preparations [43]. The first clinical iPSC pilot study is currently underway in Japan to evaluate autologous iPSC-derived retinal pigment epithelial cells for the treatment of macular degeneration [44]. Results of this trial will provide critical safety information and, hopefully, set the stage for iPSC trials in other conditions, including PD. Other groups have demonstrated the potential to transform fibroblasts directly into neurons (iN cells) or dopaminergic cells (iDA cells) with expression of the lineage-specific transcription factors Ascl1, Brn2, Mrt1l, without or with Lmxla and FoxA2, respectively [45-47]. This technology is still in early stages, however, and hurdles such as increasing the fractional yield of phenotype-specific neurons (i.e., iDA cells) and the in vivo safety of induced neural cells remain to be demonstrated.

\section{Autologous BDPCs}

The feasibility and safety of performing small-volume brain biopsies in PD patients during DBS surgery has been recently reported [27]. Prompt, meticulous culturing of the harvested tissue yielded a near-uniform, expandable cell population with phenotype attributes suggestive of glial progenitor cells and expression of multiple NTFs, including GDNF, CDNF and BDNF. The cells robustly expressed progenitor and neural markers, notably nestin, an intermediate filament protein found in pluripotent cells, Olig1, a transcription factor required for oligodendrocyte differentiation, and galactocerebroside (GalC), a myelin-associated glycolipid [48]. The co-localization of NTFs with neural and oligodendroglial proteins raised the intriguing prospect that these cells may effectively integrate back into the host brain as autologous glia and confer broad and enduring therapeutic function. The expandable cultures yielded large numbers (e.g., $10^{7}$ ) of patient cells with limited self-renewal (i.e., $\sim 10-15$ passages) that remain viable following prolonged cryostorage. The tissue source, phenotype and renewal properties favor the application of these cells in intracerebral transplantation strategies with low potential for tumorigenicity. The therapeutic potential of these cells is currently under investigation (fig. 1). 

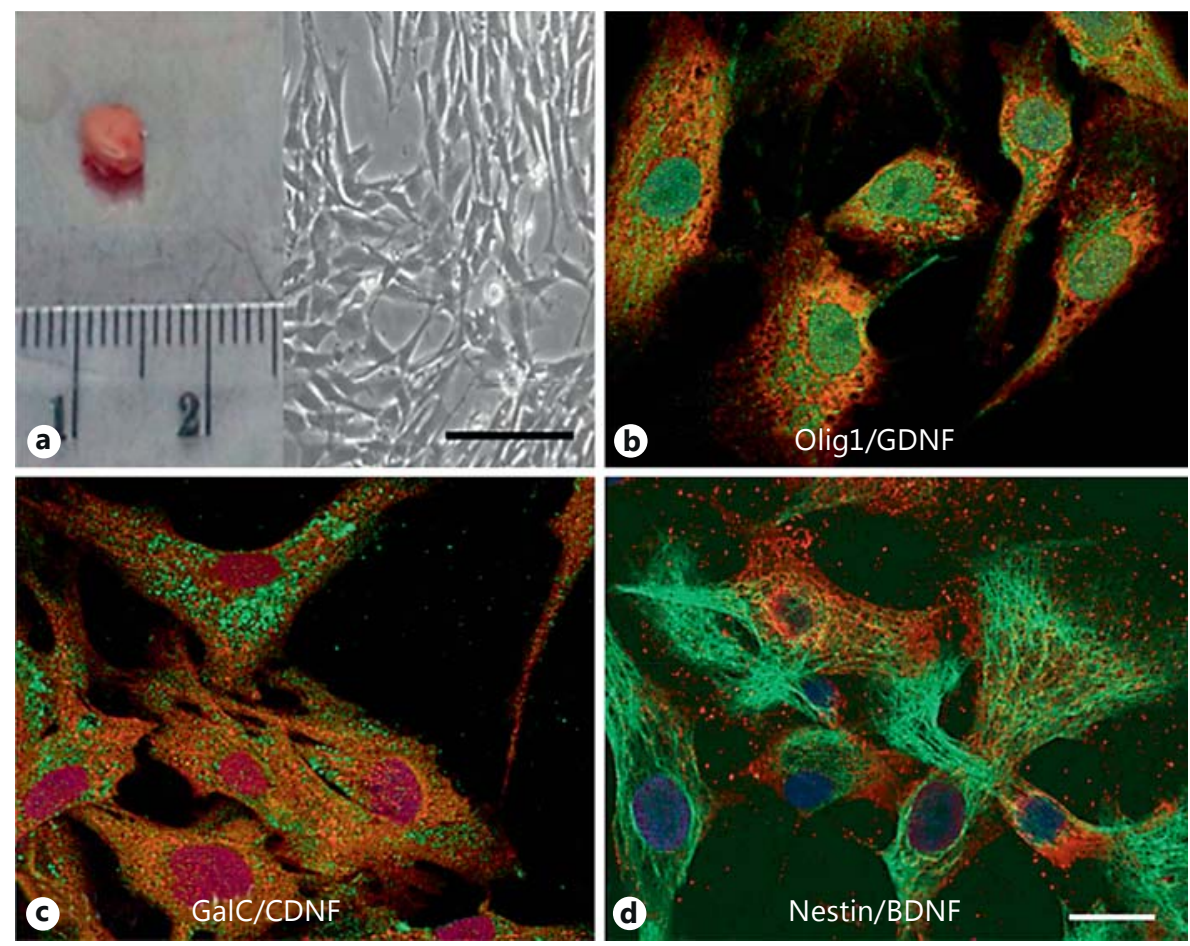

Fig. 1. Patient brain sources for autologous cell grafts. a A typical small brain biopsy harvested during DBS surgery for PD is shown (left). These specimens produce expandable cultures that yield millions of progeny cells (right) with endogenous expression of neural, progenitor and neurotrophic proteins [27]. The phenotype is consistent with a progenitor-type cell, with immature features. These patient BDPCs consistently express the oligodendrocyte markers, Olig1 and GalC, as well as the intermediate filament protein, nestin, found in many types of progenitor populations. In addition, these cells naturally co-express a broad profile of NTFs, including GDNF, CDNF and BDNF, which are some of the most potent neuroprotective molecules known in the PD field. Representative examples of this co-expression are provided by the confocal micrographs in Olig1 (green) and GDNF (red) (b), GalC (green) and CDNF (red) (c) and nestin (green) and BDNF (red) (d). The co-localization of NTFs with neural and oligodendroglial proteins raises the intriguing prospect that these cells may effectively integrate back into the host brain as autologous glia and confer broad and enduring therapeutic function. a Scale bar $=100 \mu \mathrm{m}$. b-d Scale bar $=20 \mu \mathrm{m}(\mathbf{d})$.

\section{Future Directions: Cellular Magnetic Resonance Imaging for CBT Monitoring}

In order to understand the physiology and efficacy of CBT for PD and other neurological diseases, it is necessary to develop accurate in vivo monitoring strategies to assess the viability and function of transplanted cells in the brains of recipient patients. Graft and host dopaminergic activity may be assessed using PET; however, the function of nondopaminergic cells is not directly measured with this technique. In addition, the high cost and unavailability of PET in many hospital/clinical facilities support the development of more accessible, versatile methods of CBT monitoring. Magnetic resonance imaging (MRI) provides several advantages over radionuclide imaging for monitoring CBT, including superior delineation of morphology, no exposure to radiation and the possibility of monitoring transplanted cells over long periods of time. Cell tracking with MRI is a relatively young field that aims to detect and monitor cells in living organisms. Cellular MRI combines the ability to obtain high resolution MRI data with the use of magnetic contrast agents for labeling specific cells, thereby enhancing their detectability. Most cell tracking studies have used superparamagnetic iron oxide (SPIO) nanoparticles to label cells. A variety of cell types have been successfully labeled with iron oxide agents at levels that permit their detection by MRI and without negatively impacting cell viability, phenotype or specific functions [49]. There are hundreds of publications on the use of iron oxide nanoparticles to label or track stem cells, and much of the work has focused on experimental models of CNS disease. Some examples have included imaging of ironlabeled neural stem cells transplanted into an embryonic mouse brain [50], iron-labeled oligodendroglial progeni- 

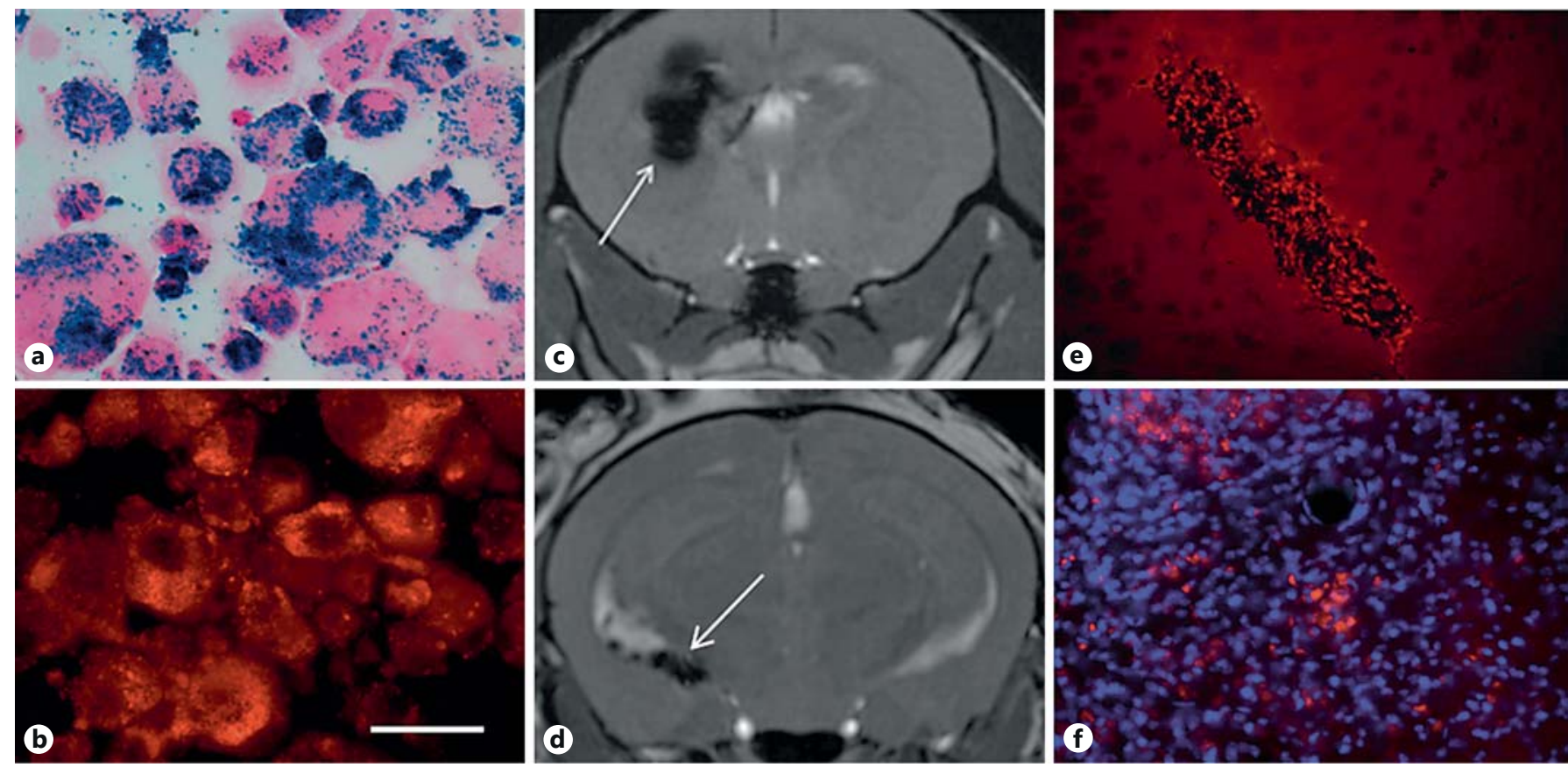

Fig. 2. MRI cell tracking for monitoring CBT. Human PD patient BDPCs may be labeled with iron nanoparticles that permit MRI tracking following implantation in the brain. An efficient labeling technique for experimental studies uses the Molday ion rhodamine B (MIRB) SPIO to dually identify grafted cells by iron uptake, as visualized here in vitro using Prussian blue stain (a) and bright red emission under fluorescence microscopy (b). Balanced steadystate free precession MRI images demonstrated MIRB-labeled human PD patient BDPCs following intracerebral transplantation into the striatum (c) and in the lateral ventricle (d) of an immunodeficient mouse (NOD/SCID IL2 receptor knockout) 4 weeks after surgery (arrows). e Fluorescence microscopy may be used to confirm the location and viability of the cells in histological sections, as seen here in a deposit of MIRB-labeled human PD patient BDPCs implanted into a mouse striatum 2 days prior. The red signal emanates from the fluorochrome, while the dark signal is produced by the iron particles in the SPIO. $f$ After 4 weeks, human PD $\mathrm{BDPC}$ remain viable as evident by the red fluorescent signal labeling the cells in the striatum. The actual transplantation site is indicated by the arrow in the MRI shown in c. The nuclear stain $4^{\prime}, 6$ diamidino-2-phenylindole provides blue background labeling of regional host cell nuclei. a, b Scale bar $=25 \mu \mathrm{m}$ (b). $\mathbf{e} \times 10 . \mathbf{f} \times 40$. tors transplanted into the ventricles of a neonatal, myelin deficient rat brain [51] and iron-labeled human stem cells transplanted into the striatum of parkinsonian rats [52]. In vivo cell tracking is potentially a powerful tool that can provide critical feedback regarding the optimal protocols for CBT and reveal important information about the mechanisms of cell homing, engraftment and survival. The efficient internalization of iron nanoparticles is well documented; uptake by cells leads to subsequent compartmentalization in secondary endosomes within the cell cytoplasm. The presence of intracellular iron causes a distortion in the magnetic field, with areas containing iron-labeled cells appearing as regions of low signal intensity. The magnetic susceptibility of these particles affects an area larger than the actual size of the particles, facilitating the detection of labeled cells (fig. 2). Other strategies to enhance MRI cell tracking include genetically engineering the graft cells to enhance the function of intracellular ironregulatory proteins that act as endogenous contrast agents [53]. SPIO and genetic MRI contrast enhancement methods remain in early stages of development but offer tremendous potential for clinical application in CBT.

\section{Conclusions}

There remains a critical need for innovative strategies to treat $\mathrm{PD}$ and other neurodegenerative diseases. Advances in NTF technology and CBT may prove highly complementary and offer hope for effective restoration and preservation treatments. As these methods develop, it will be important to integrate related aspects of genetics, neuroimaging and pharmacotherapy in order to craft and optimize personalized and definitive care for these patients. 


\section{References}

1 de Lau LM, Breteler MM: Epidemiology of Parkinson's disease. Lancet Neurol 2006;5: 525-535.

2 Thenganatt MA, Jankovic J: Parkinson disease subtypes. JAMA Neurol 2014;71:499504.

3 Hughes AJ, Daniel SE, Kilford L, Lees AJ: Accuracy of clinical diagnosis of idiopathic Parkinson's disease: a clinico-pathological study of 100 cases. J Neurol Neurosurg Psychiatry 1992;55:181-184.

4 Brotchie JM, Lee J, Venderova K: Levodopainduced dyskinesia in Parkinson's disease. J Neural Transm 2005;112:359-391.

5 Marsden CD, Parkes JD: 'On-off effects in patients with Parkinson's disease on chronic levodopa therapy. Lancet 1976;1:292-296.

-6 Benabid AL, Chabardes S, Mitrofanis J, Pollak P: Deep brain stimulation of the subthalamic nucleus for the treatment of Parkinson's disease. Lancet Neurol 2009;8:67-81.

7 Rodrigues TM, Jeronimo-Santos A, Outeiro TF, Sebastiao AM, Diogenes MJ: Challenges and promises in the development of neurotrophic factor-based therapies for Parkinson's disease. Drugs Aging 2014;31:239-261.

8 Aron L, Klein R: Repairing the parkinsonian brain with neurotrophic factors. Trends Neurosci 2011;34:88-100.

-9 Kordower JH, Bjorklund A: Trophic factor gene therapy for Parkinson's disease. Mov Disord 2013;28:96-109.

$\checkmark 10$ Lin LF, Doherty DH, Lile JD, Bektesh S, Collins F: GDNF: a glial cell line-derived neurotrophic factor for midbrain dopaminergic neurons. Science 1993;260:1130-1132.

$\checkmark 11$ Gash DM, Zhang Z, Ovadia A, Cass WA, Yi A, Simmerman L, Russell D, Martin D, Lapchak PA, Collins F, Hoffer BJ, Gerhardt GA: Functional recovery in parkinsonian monkeys treated with GDNF. Nature 1996;380: 252-255.

12 Nutt JG, Burchiel KJ, Comella CL, Jankovic J, Lang AE, Laws ER Jr, Lozano AM, Penn RD, Simpson RK Jr, Stacy M, Wooten GF: Randomized, double-blind trial of glial cell linederived neurotrophic factor (GDNF) in PD. Neurology 2003;60:69-73.

13 Gill SS, Patel NK, Hotton GR, O'Sullivan K, McCarter R, Bunnage M, Brooks DJ, Svendsen CN, Heywood P: Direct brain infusion of glial cell line-derived neurotrophic factor in Parkinson disease. Nat Med 2003;9:589-595.

14 Patel NK, Bunnage M, Plaha P, Svendsen CN, Heywood P, Gill SS: Intraputamenal infusion of glial cell line-derived neurotrophic factor in PD: a two-year outcome study. Ann Neurol 2005;57:298-302.

15 Patel NK, Pavese N, Javed S, Hotton GR, 24 Brooks DJ, Gill SS: Benefits of putaminal GDNF infusion in Parkinson disease are maintained after GDNF cessation. Neurology 2013;81:1176-1178.

16 Slevin JT, Gerhardt GA, Smith CD, Gash DM, Kryscio R, Young B: Improvement of bilat- eral motor functions in patients with Parkinson disease through the unilateral intraputaminal infusion of glial cell line-derived neurotrophic factor. J Neurosurg 2005; 102: 216-222.

17 Lang AE, Gill S, Patel NK, Lozano A, Nutt JG, Penn R, Brooks DJ, Hotton G, Moro E, Heywood P, Brodsky MA, Burchiel K, Kelly P, Dalvi A, Scott B, Stacy M, Turner D, Wooten VG, Elias WJ, Laws ER, Dhawan V, Stoessl AJ, Matcham J, Coffey RJ, Traub M: Randomized controlled trial of intraputamenal glial cell linederived neurotrophic factor infusion in Parkinson disease. Ann Neurol 2006;59:459-466.

18 Kotzbauer PT, Lampe PA, Heuckeroth RO, Golden JP, Creedon DJ, Johnson EM Jr, Milbrandt J: Neurturin, a relative of glial-cellline-derived neurotrophic factor. Nature 1996;384:467-470.

19 Horger BA, Nishimura MC, Armanini MP, Wang LC, Poulsen KT, Rosenblad C, Kirik D, Moffat B, Simmons L, Johnson E Jr, Milbrandt J, Rosenthal A, Bjorklund A, Vandlen RA, Hynes MA, Phillips HS: Neurturin exerts potent actions on survival and function of midbrain dopaminergic neurons. J Neurosci 1998;18:4929-4937.

20 Grondin R, Zhang Z, Ai Y, Ding F, Walton AA, Surgener SP, Gerhardt GA, Gash DM: Intraputamenal infusion of exogenous neurturin protein restores motor and dopaminergic function in the globus pallidus of MPTPlesioned rhesus monkeys. Cell Transplant 2008; 17:373-381.

21 Kordower JH, Herzog CD, Dass B, Bakay RA, Stansell J 3rd, Gasmi M, Bartus RT: Delivery of neurturin by AAV2 (CERE-120)-mediated gene transfer provides structural and functional neuroprotection and neurorestoration in MPTP-treated monkeys. Ann Neurol 2006; 60:706-715.

22 Herzog CD, Brown L, Gammon D, Kruegel B, Lin R, Wilson A, Bolton A, Printz M, Gasmi M, Bishop KM, Kordower JH, Bartus RT: Expression, bioactivity, and safety 1 year after adeno-associated viral vector type 2-mediated delivery of neurturin to the monkey nigrostriatal system support cere-120 for Parkinson's disease. Neurosurgery 2009;64:602612; discussion 612-613.

23 Marks WJ Jr, Ostrem JL, Verhagen L, Starr PA, Larson PS, Bakay RA, Taylor R, CahnWeiner DA, Stoessl AJ, Olanow CW, Bartus RT: Safety and tolerability of intraputaminal delivery of CERE-120 (adeno-associated virus serotype 2-neurturin) to patients with idiopathic Parkinson's disease: an open-label, phase I trial. Lancet Neurol 2008;7:400-408.

Marks WJ Jr, Bartus RT, Siffert J, Davis CS, Lozano A, Boulis N, Vitek J, Stacy M, Turner D, Verhagen L, Bakay R, Watts R, Guthrie B, Jankovic J, Simpson R, Tagliati M, Alterman R, Stern M, Baltuch G, Starr PA, Larson PS, Ostrem JL, Nutt J, Kieburtz K, Kordower JH, Olanow CW: Gene delivery of AAV2-neur- turin for Parkinson's disease: a double-blind, randomised, controlled trial. Lancet Neurol 2010;9:1164-1172.

-25 Bartus RT, Herzog CD, Chu Y, Wilson A, Brown L, Siffert J, Johnson EM Jr, Olanow CW, Mufson EJ, Kordower JH: Bioactivity of AAV2-neurturin gene therapy (CERE-120): differences between Parkinson's disease and nonhuman primate brains. Mov Dis 2011;26: 27-36.

26 Bartus RT, Baumann TL, Siffert J, Herzog CD, Alterman R, Boulis N, Turner DA, Stacy M, Lang AE, Lozano AM, Olanow CW: Safety/ feasibility of targeting the substantia nigra with AAV2-neurturin in Parkinson patients. Neurology 2013;80:1698-1701.

-27 Xu H, Belkacemi L, Jog M, Parrent A, Hebb MO: Neurotrophic factor expression in expandable cell populations from brain samples in living patients with Parkinson's disease. FASEB J 2013;27:4157-4168.

28 Ishii T, Eto K: Fetal stem cell transplantation: past, present, and future. World J Stem Cells 2014;6:404-420.

29 Lindvall $\mathrm{O}$, Widner $\mathrm{H}$, Rehncrona S, Brundin P, Odin P, Gustavii B, Frackowiak R, Leenders KL, Sawle G, Rothwell JC, et al: Transplantation of fetal dopamine neurons in Parkinson's disease: one-year clinical and neurophysiological observations in two patients with putaminal implants. Ann Neurol 1992;31:155165.

-30 Freed CR, Greene PE, Breeze RE, Tsai WY, DuMouchel W, Kao R, Dillon S, Winfield H, Culver S, Trojanowski JQ, Eidelberg D, Fahn S: Transplantation of embryonic dopamine neurons for severe parkinson's disease. $\mathrm{N}$ Engl J Med 2001;344:710-719.

31 Olanow CW, Goetz CG, Kordower JH, Stoessl AJ, Sossi V, Brin MF, Shannon KM, Nauert GM, Perl DP, Godbold J, Freeman TB: A double-blind controlled trial of bilateral fetal nigral transplantation in Parkinson's disease. Ann Neurol 2003;54:403-414.

-32 Ma Y, Tang C, Chaly T, Greene P, Breeze R, Fahn S, Freed C, Dhawan V, Eidelberg D: Dopamine cell implantation in Parkinson's disease: long-term clinical and (18)F-FDOPA PET outcomes. J Nucl Med 2010;51:7-15.

- 33 Thomson JA, Itskovitz-Eldor J, Shapiro SS, Waknitz MA, Swiergiel JJ, Marshall VS, Jones JM: Embryonic stem cell lines derived from human blastocysts. Science 1998;282:11451147.

34 Perrier AL, Tabar V, Barberi T, Rubio ME, Bruses J, Topf N, Harrison NL, Studer L: Derivation of midbrain dopamine neurons from human embryonic stem cells. Proc Natl Acad Sci USA 2004;101:12543-12548.

35 Roy NS, Cleren C, Singh SK, Yang L, Beal MF, Goldman SA: Functional engraftment of human ES cell-derived dopaminergic neurons enriched by coculture with telomerase-immortalized midbrain astrocytes. Nat Med 2006;12:1259-1268. 
36 Takagi Y, Takahashi J, Saiki H, Morizane A, Hayashi T, Kishi Y, Fukuda H, Okamoto Y, Koyanagi M, Ideguchi M, Hayashi H, Imazato T, Kawasaki H, Suemori H, Omachi S, Iida H, Itoh N, Nakatsuji N, Sasai Y, Hashimoto N: Dopaminergic neurons generated from monkey embryonic stem cells function in a Parkinson primate model. J Clin Invest 2005;115: 102-109.

-37 Glavaski-Joksimovic A, Bohn MC: Mesenchymal stem cells and neuroregeneration in Parkinson's disease. Exp Neurol 2013;247: 25-38.

38 Venkataramana NK, Kumar SK, Balaraju S, Radhakrishnan RC, Bansal A, Dixit A, Rao DK, Das M, Jan M, Gupta PK, Totey SM: Open-labeled study of unilateral autologous bone-marrow-derived mesenchymal stem cell transplantation in Parkinson's disease. Transl Res 2010;155:62-70.

39 Takahashi K, Yamanaka S: Induction of pluripotent stem cells from mouse embryonic and adult fibroblast cultures by defined factors. Cell 2006;126:663-676.

40 Ross CA, Akimov SS: Human-induced pluripotent stem cells: potential for neurodegenerative diseases. Hum Mol Genet 2014; 23:R17-R26.

41 Wernig M, Zhao JP, Pruszak J, Hedlund E, Fu D, Soldner F, Broccoli V, Constantine-Paton $\mathrm{M}$, Isacson $\mathrm{O}$, Jaenisch R: Neurons derived from reprogrammed fibroblasts functionally integrate into the fetal brain and improve symptoms of rats with Parkinson's disease. Proc Natl Acad Sci USA 2008;105:5856-5861.
2 Hargus G, Cooper O, Deleidi M, Levy A, Lee K, Marlow E, Yow A, Soldner F, Hockemeyer D, Hallett PJ, Osborn T, Jaenisch R, Isacson O: Differentiated Parkinson patient-derived induced pluripotent stem cells grow in the adult rodent brain and reduce motor asymmetry in parkinsonian rats. Proc Natl Acad Sci USA 2010;107:15921-15926.

43 Momcilovic O, Liu Q, Swistowski A, RussoTait T, Zhao Y, Rao MS, Zeng X: Genome wide profiling of dopaminergic neurons derived from human embryonic and induced pluripotent stem cells. Stem Cells Dev 2014; 23:406-420.

44 Reardon S, Cyranoski D: Japan stem-cell trial stirs envy. Nature 2014;513:287-288.

-45 Pang ZP, Yang N, Vierbuchen T, Ostermeier A, Fuentes DR, Yang TQ, Citri A, Sebastiano V, Marro S, Sudhof TC, Wernig M: Induction of human neuronal cells by defined transcription factors. Nature 2011;476:220-223.

46 Pfisterer U, Kirkeby A, Torper O, Wood J, Nelander J, Dufour A, Bjorklund A, Lindvall O, Jakobsson J, Parmar M: Direct conversion of human fibroblasts to dopaminergic neurons. Proc Natl Acad Sci USA 2011;108: 10343-10348.

47 Chanda S, Ang CE, Davila J, Pak C, Mall M, Lee QY, Ahlenius H, Jung SW, Sudhof TC, Wernig M: Generation of induced neuronal cells by the single reprogramming factor ascl1. Stem Cell Reports 2014;3:282-296.
48 Baumann N, Pham-Dinh D: Biology of oligodendrocyte and myelin in the mammalian central nervous system. Physiol Rev 2001;81: 871-927.

49 Li L, Jiang W, Luo K, Song H, Lan F, Wu Y, GuZ: Superparamagneticiron oxide nanoparticles as MRI contrast agents for non-invasive stem cell labeling and tracking. Theranostics 2013;3:595-615.

50 Tang H, Sha H, Sun H, Wu X, Xie L, Wang P, Xu C, Larsen C, Zhang HL, Gong Y, Mao Y, Chen X, Zhou L, Feng X, Zhu J: Tracking induced pluripotent stem cells-derived neural stem cells in the central nervous system of rats and monkeys. Cellular Reprogram 2013;15: 435-442.

51 Bulte JW, Duncan ID, Frank JA: In vivo magnetic resonance tracking of magnetically labeled cells after transplantation. J Cereb Blood Flow Metab 2002;22:899-907.

-52 Stroh A, Boltze J, Sieland K, Hild K, Gutzeit C, Jung T, Kressel J, Hau S, Reich D, Grune T, Zimmer C: Impact of magnetic labeling on human and mouse stem cells and their longterm magnetic resonance tracking in a rat model of Parkinson disease. Mol Imaging 2009;8:166-178.

53 Goldhawk DE, Rohani R, Sengupta A, Gelman N, Prato FS: Using the magnetosome to model effective gene-based contrast for magnetic resonance imaging. Wiley Interdiscip Rev Nanomed Nanobiotechnol 2012;4:378388.

\section{Erratum}

The authors of the paper by H.-J. Ko et al. entitled 'Effect of pet insects on the psychological health of community-dwelling elderly people: a single-blinded, randomized, controlled trial' [Gerontology 2016;62:200-209] wish to add the following text:

\section{Acknowledgments}

This study was performed with the support of the Research Program for Agricultural Science \& Technology Development (PJ009600032015), National Academy of Agricultural Science, Rural Development Administration, Korea. All data collection and analyses were performed by the authors. The sponsors had no influence on the study design, data acquisition, data analysis, data interpretation, or writing of the manuscript. 